\title{
Changes in the quality of goat meat in the production of smoked ham
}

\author{
Ivanović Snežana ${ }^{1}$, Pisinov Boris ${ }^{1}$, Bošković Marija ${ }^{2}$, Ivanović Jelena ${ }^{2}$, Marković Radmila ${ }^{2}$, Baltić Ž. Milan ${ }^{2}$, \\ Nešić Ksenija ${ }^{1}$
}

A b s tra c t: The quality of fresh goat meat can be defined strictly in terms of physical and chemical properties, or in terms of consumer perception. In Serbia, there is not enough information about the quality of goat meat and goat meat products, such as smoked ham. The aim of this study was to determine differences in the basic chemical composition, colour, fatty acids composition, volatile compounds in fresh meat and smoked ham (musculus gluteus superficialis). The meat was obtained from the population of Serbian White goat, five or six years old. ISO methods were implemented in order to determine the quality of these parameters.

Statistically significant difference $(p<0.05)$ was determined between values of protein, fat, moisture, ash, $p H$ value, fatty acids and volatile compounds determined in fresh meat and finished product (smoked ham). It is assumed that the complex chemical and biochemical processes occurring during production (growing, curing, smoking, drying) resulted in statistically significant differences between the quality parameters in fresh meat and smoked ham. There was a statistically significant difference $(p<0.05)$ between the values of capric acid, lauric acid, myristic acid, pentadecanoic acid, pentadecenoic acid, palmitic acid, palmitoleic acid, heptadecanoic acid, stearic acid, oleic acid, linoleic acid, linolenic acid, arachidic acid and gadoleic acid identified in the thigh meat prepared for curing and smoking in compared to value of the fatty acids identified in the final product (smoked ham).

Key words: goats, meat quality, maturation, curing, smoking.

\section{Introduction}

The general definition of meat quality, including goat meat quality, is referring to meat safety (pathogenic microorganisms, toxins, heavy metals, pesticides and antibiotics residues, etc.), physical and chemical properties of meat and palatability (Webb et al., 2005; Casey and Webb, 2010). Parameters which define the quality of goat meat, as noted by Webb et al. (2005), are discovered and continually redefined. Goat meat quality depends on the biological factors including the age and sex of the animal, as well as other factors such as pre-slaughter stress, slaughter techniques and carcass cooling and freezing practices.

Physiological state of live animals and postmortem biochemical changes in muscle, fat and fibrous tissue have a direct impact on the meat palatability. Animal feeding affects quality of the meat by muscle growth, muscle and fat ratio, fat accumulation and the fatty acid composition (Casey and Webb, 2010). Goat meat is an important source of proteins worldwide, especially in developing countries (Biswas et al., 2007). It has about the same nutritional value as sheep meat (contains more proteins and less fat compared to sheep meat). Anaeto et al. (2010) has considered that goat meat is easier to digest as a result of its molecular structure. Because goat meat contains low amount of saturated fatty acids and cholesterol, according Anaeto et al. (2010), it presents a healthier alternative compared to other types of red meat. According to the same author, polyunsaturated fatty acids are prevalent in goat meat and diet rich in unsaturated fatty acids is correlated with a reduced risk of stroke and coronary heart disease, which indicates important role of goat meat in human diet. Regardless of the nutritional value, goat meat is still less appreciated because of specific taste which is even more present in older animals (Ivanović et al., 2011).

Acknowledgements: This paper was supported by the Ministry of Education, Science and Technological development, Republic of Serbia, Project TR 31053.

${ }^{1}$ Institute of Veterinary Medicine of Serbia, Autoput br. 3, 11000 Belgrade, Republic of Serbia;

${ }^{2}$ University of Belgrade, Faculty of Veterinary Medicine Belgrade, Bulevar oslobođenja 18, 11000 Belgrade, Republic of Serbia.

Corresponding author: Ivanović Snežana, snezaivanovic@gmail.com 
The fatty acids in the muscle tissue affect meat quality, including tenderness, color, stability of lipid and flavour (Wood et al., 2004). In the transformation of fatty acids substances are formed which directly affect the smell and taste of goat meat. Slightly rancid odor is caused by hexanal which comes mainly from linoleic and arachidonic acid (Martin et al., 2002). Other volatile aldehydes such as heptanal, octanal, nonanal and decanal derive mainly from oleic acid (Machiels et al., 2004). Fatty acids have been specifically implicated in sheep and goat flavors. 4-ethylocatanoic fatty acid is mainly responsible for strong smell of goat meat. This acid was detected in goat meat, lamb and mutton, as well as in cheeses made from milk from these species. In addition to fatty acids, taste and aroma are also affected by other compounds: hydrocarbons, aldehydes, ketones, alcohols, furans, thiophenes, pyrrols, pyrazines, oxazoles, thiazoles, and sulfurous compounds (Todaro et al., 2004). Goat meat has a significant role in human nutrition because it contains essential amino acids such as lysine, threonine and tryptophan. Goat breeding and goat meat consumption, despite mentioned qualitative composition, are determined by religion, tradition and customs as well as market and consumer habits (Ivanović et al., 2009). In Serbia, there are not enough information about the quality of goat meat and goat meat products such as smoked ham. The aim of this study was to determine differences in the basic chemical composition, colour, fatty acids composition, volatile compounds of fresh meat and smoked ham (m. gluteus superficialis), which come from the Serbian population of white goat breed, aged five or six years.

\section{Material and methods}

Twenty culled Serbian white goats, 5-6 years old were used. All animals were selected from private farms in the rural area of Stara Planina Mountain. The goats were raised during the same period . Facilities for housing of goats were built of mixed solid materials and covered with ceramic tiles, with conditions that were satisfactory for goat breeding. The floor was stuffed soil and covered by thick layer of wheat straw. Watering was ad libitum.

The diet for goats during the winter consisted of hay which was collected from natural pastures (3.5 kg/day per animal) and concentrate $(0.25 \mathrm{~kg} /$ day per animal). In the summer months, the goats were pastured and fed with concentrate in the amount of $0.25 \mathrm{~kg} /$ day. The concentrate was made of maize meal, wheat bran with added sodium chloride and premix.
The animals were slaughtered in the experimental slaughter house of the Institute for Animal Husbandry. The carcasses were processed in the way common for industrial production, and cooled at $4^{\circ} \mathrm{C}$ for 48 hours.

Processed goat hams with associated bones were dry salted using about $6 \%$ nitrite salt $(99.5 \%$ sodium chloride and $0.5 \%$ sodium nitrite). Hams were kept in nitrite salt for 30 days at $5^{\circ} \mathrm{C}$. During the salting period they were rotated every two days. Desalting was carried out in cold water for $24 \mathrm{~h}$, the water was changed four times. Hams were coldsmoked for 45 days on moderate air circulation, humidity $70-78 \%$. The smoke temperature did not exceed $20^{\circ} \mathrm{C}$. During the first 10 days, the smoking was carried out every day for 2 hours, but between the 10th and 45th day it was done every two days for 2 hours. After the smoking period, hams were air dried $\left(18-20^{\circ} \mathrm{C}\right)$ for another 45 days.

The material used for the determination of chemical composition, fatty acids and volatile compounds was $m$. gluteus superficialis. Moisture content was determined according to ISO 1442:1997, fat content according to ISO 1443:1973 and ash content according to ISO 936:1998. The protein content was calculated from nitrogen content multiplied with 6.25 using ISO 937:1978, sodium chloride content was determined according to ISO 1841-1:1996, pH value according to ISO 2917:1999 and nitrite content according to ISO 2918:1975.

AOAC method $(1996,2001)$ was applied for fat extraction from tissue, methylation with boron trifluoride reagent and GC determination. Analysis of FAMEs was performed by an internal standard method using a gas chromatograph (GC6890N, Agilent Tech., USA) with column DB-23 (60m $\times$ $0.25 \mathrm{~mm}$ ID, $0.15 \mu \mathrm{m}$ ) and comparing with standard mix of FAMEs 37 (Supelco, USA).

Volatile compounds analysis was conducted by Likens-Nickerson extraction procedure (Likens et al., 1964) and by gas chromatographic-mass spectral analysis using an GCMS-QP2010 Ultra (EIMS, electron energy $=70 \mathrm{eV}$, scan range $=30-350 \mathrm{amu}$, and scan rate $=3.99 \mathrm{scans} / \mathrm{s}$ ) with SUPELCOWAX ${ }^{\circledR} 10$ Capillary GC Column (30 m x 0.25 mm ID, particle size $0.25 \mu \mathrm{m})$. The carrier gas was helium with a flow rate of $1 \mathrm{~mL} / \mathrm{min}$, and the injection temperature was $200^{\circ} \mathrm{C}$. The oven temperature was programmed to initially hold for $10 \mathrm{~min}$ at $40^{\circ} \mathrm{C}$, and subsequently programmed from $40^{\circ} \mathrm{C}$ to $120^{\circ} \mathrm{C}$ at a rate of $3^{\circ} \mathrm{C} / \mathrm{min}$ and at a rate of $10^{\circ} \mathrm{C} / \mathrm{min}$ from $120^{\circ} \mathrm{C}$ to $250^{\circ} \mathrm{C}$ where it was held for another $5 \mathrm{~min}$. Identification of the peaks was based on comparison of their mass spectra with the spectra of the WILEY library and in addition, in some cases, by 
comparison of their retention times with those of standard compounds.

The colour was measured on the fresh and smoked meat cuts (musculus superficial gluteal), from the right side of each carcass. CIE L*a*b* colour coordinates (CIE Colorimetry, 1986) were determined using Minolta Chromameter CR 400 (Minolta Co. Ltd., Osaka, Japan) in D-65 lighting, with standard angle of 2 degrees of shelter and $8 \mathrm{~mm}$ aperture of the measuring head. These results were expressed in CIE L*a*b* and were given as the mean values: $\mathrm{L}^{*}$ (psychometer light), a* (psychometer tone) and $\mathrm{b}^{*}$ (psychometer chroma).

Data obtained in this study were analysed by descriptive and analytical statistical parameters: mean value $(M)$, standard deviation (SD) by using MS Excel 2003 and analysis of variance (ANOVA). The differences between the averages were compared by t-test at the level of significance of $95 \%$.

\section{Results and discussion}

The results of chemical composition and $\mathrm{pH}$ value of fresh goat meat and ham are shown in Table 1.

Results presented in Table 1 showed that there was a statistically significant difference $(p<0.05)$ between the values of protein, fat, moisture, ash and $\mathrm{pH}$ value in fresh goat meat and the value of protein, fat, moisture, ash and $\mathrm{pH}$ value determined in the finished product (smoked ham). Sodium chloride and nitrites were determined only in smoked ham.

The results of the fatty acid composition in $m$. gluteus superficialis of goat meat and smoked ham from these goats are presented in Table 2.

There were statistically significant differences $(p<0.05)$ between the values of capric acid, lauric acid, myristic acid, pentadecanoic acid, pentadecenoic acid, palmitic acid, palmitoleic acid, heptadecanoic acid, stearic acid, oleic acid, linoleic acid, linolenic acid, arachidic acid and gadoleic acid identified in the thigh meat prepared for curing and smoking compared to value of the fatty acids identified in the final product (smoked ham). The ratio of unsaturated/saturated fatty acids was 0.83 in fresh meat and 0.55 in smoked ham.

Table 3 shows the results obtained by analysing the presence of specific volatile substances in fresh meat and smoked ham.

Some volatile compounds, such as, benzene, ethylbenzene, phenol, 2-methyl-phenol and 2-methoxy-phenol were not detected in fresh goat meat while 2-pentanol and 1-octen-3-ol were not detected in smoked ham.

In this study no statistically significant differences $(p>0.05)$ were found between butanoic acid and octane. There were statistically significant differences $(p<0.05)$ between other volatile compounds determined in fresh meat and smoked ham (table 3).

Colour parameters $\left(L^{*} a^{*} b^{*}\right)$ of fresh meat samples taken from a goat leg and samples of

Table 1. The basic chemical composition and $\mathrm{pH}$ value of fresh goat meat and smoked ham

Tabela 1. Osnovni hemijski sastav i pH vrednost svežeg kozijeg mesa i dimljene šunke

\begin{tabular}{|l|c|c|l|c|c|}
\hline \multicolumn{3}{|c|}{ Fresh meat/Sveže meso } & \multicolumn{3}{c|}{ Smoked ham/Dimljena šunka } \\
\hline $\begin{array}{l}\text { Parameter/ } \\
\text { Parametar }\end{array}$ & $\mathrm{n}$ & $\mathrm{M} \pm \mathrm{SD}$ & $\begin{array}{l}\text { Parameter/ } \\
\text { Parametar }\end{array}$ & $\mathrm{n}$ & $\mathrm{M} \pm \mathrm{SD}$ \\
\hline Protein/Protein, \% & 20 & $20.1 \pm 0.8^{\mathrm{a}}$ & Protein/Protein, $\%$ & 20 & $37.9 \pm 0.9^{\mathrm{b}}$ \\
\hline Fat/Mast, \% & 20 & $3.5 \pm 0.7^{\mathrm{a}}$ & Fat/Mast, \% & 20 & $16.1 \pm 1.0^{\mathrm{b}}$ \\
\hline Moisture/Vlaga, \% & 20 & $74.9 \pm 0.8^{\mathrm{b}}$ & Moisture/Vlaga, \% & 20 & $39.1 \pm 0.7^{\mathrm{a}}$ \\
\hline Ash/Pepeo, \% & 20 & $1.04 \pm 0.04^{\mathrm{a}}$ & Ash/Pepeo, \% & 20 & $5.6 \pm 0.2^{\mathrm{b}}$ \\
\hline $\begin{array}{l}\text { Sodium chloride/ } \\
\text { Natrijum-hlorid, \% }\end{array}$ & 20 & nd & $\begin{array}{l}\text { Sodium chloride/ } \\
\text { Natrijum-hlorid, } \%\end{array}$ & 20 & $4.7 \pm 0.1$ \\
\hline Nitrites/Nitriti, $\mathrm{mg} / \mathrm{kg}$ & 20 & $\mathrm{nd}$ & Nitrites/Nitriti, $\mathrm{mg} / \mathrm{kg}$ & 20 & $27.0 \pm 1.0$ \\
\hline $\begin{array}{l}\mathrm{pH} \text { value/ } \\
\mathrm{pH} \text { vrednost }\end{array}$ & 20 & $5.71 \pm 0.06^{\mathrm{a}}$ & $\begin{array}{l}\mathrm{pH} \text { value/ } \\
\mathrm{pH} \text { vrednost }\end{array}$ & 20 & $5.52 \pm 0.04^{\mathrm{b}}$ \\
\hline
\end{tabular}

Legend/Legenda: a, b Means within the same row with different superscripts differ significantly $(p<0.05)$, nd - not determined/a,b srednje vrednosti u istom redu sa različitim znakom se značajno razlikuju $(p<0,05)$, nd - nije određeno 
Table 2. The fatty acid composition (\% of total fatty acids) of fresh goat meat and smoked ham Tabela 2. Sastav masnih kiselina (\% od ukupnih masnih kiselina) svežeg kozijeg mesa i dimljene šunke

\begin{tabular}{|c|c|c|}
\hline \multirow[b]{2}{*}{ Fatty acids/Masne kiseline, $n=20$} & \multicolumn{2}{|c|}{$\mathbf{M} \pm \mathbf{S D}$} \\
\hline & $\begin{array}{l}\text { Fresh meat/Sveže meso } \\
\qquad \mathbf{n}=\mathbf{2 0}\end{array}$ & $\begin{array}{c}\text { Smoked ham/Dimljena šunka } \\
n=20\end{array}$ \\
\hline Capric acid/Kaprinska kiselina (C10:0) & $0.30 \pm 0.05^{\mathrm{a}}$ & $0.46 \pm 0.08^{b}$ \\
\hline Lauric acid/Laurinska kiselina (C12:0) & $1.15 \pm 0.12^{\mathrm{a}}$ & $1.54 \pm 0.15^{b}$ \\
\hline Myristic acid/Miristinska kiselina (C14:0) & $9.30 \pm 1.15^{\mathrm{a}}$ & $11.03 \pm 1.22^{b}$ \\
\hline Pentadecanoic acid/Pentadekanska kiselina (C15:0) & $2.46 \pm 0.30^{\mathrm{a}}$ & $3.31 \pm 0.45^{b}$ \\
\hline Pentadecenoic acid/ Pentadekenska kiselina (C15:1) & $0.20 \pm 0.05^{b}$ & $0.12 \pm 0.02^{\mathrm{a}}$ \\
\hline Palmitic acid/Palmitinska kiselina (C16:0) & $25.95 \pm 2.13^{\mathrm{a}}$ & $29.28 \pm 2.50^{\mathrm{b}}$ \\
\hline Palmitoleic acid/Palmitoleinska kiselina (C16:1) & $4.24 \pm 0.40^{\mathrm{b}}$ & $2.38 \pm 0.45^{\mathrm{a}}$ \\
\hline Heptadecanoic acid/Heptadekanska kiselina (C17:0) & $1.35 \pm 0.15^{\mathrm{a}}$ & $2.05 \pm 0.22^{b}$ \\
\hline Stearic acid/Stearinska kiselina (C18:0) & $13.70 \pm 1.32^{\mathrm{a}}$ & $16.35 \pm 1.65^{b}$ \\
\hline Oleic acid/Oleinska kiselina (C18:1) & $36.20 \pm 2.80^{b}$ & $31.15 \pm 2.55^{\mathrm{a}}$ \\
\hline Linoleic acid/Linolna kiselina (C18:2) & $3.40 \pm 0.30^{\mathrm{b}}$ & $1.45 \pm 0.14^{\mathrm{a}}$ \\
\hline Linolenic acid/Linolenska kiselina (C18:3) & $1.21 \pm 0.15^{\mathrm{b}}$ & $0.30 \pm 0.10^{\mathrm{a}}$ \\
\hline Arachidic acid/Arahidonska kiselina (C20:0) & $0.32 \pm 0.05^{\mathrm{a}}$ & $0.45 \pm 0.10^{\mathrm{b}}$ \\
\hline Gadoleic acid/Gadoleinska kiselina (C20:1) & $0.21 \pm 0.05^{\mathrm{b}}$ & $0.10 \pm 0.05^{\mathrm{a}}$ \\
\hline$\Sigma$ SFA (Saturated Fatty Acid/Zasićene masne kiseline) & $54.53 \pm 5.27^{\mathrm{a}}$ & $64.47 \pm 6.37^{b}$ \\
\hline $\begin{array}{l}\Sigma \text { MUFA(Monounsaturated fatty acids/Mononezasićene } \\
\text { masne kiseline) }\end{array}$ & $40.85 \pm 3.30^{\mathrm{b}}$ & $33.75 \pm 3.07^{\mathrm{a}}$ \\
\hline $\begin{array}{l}\Sigma \text { PUFA (Polyunsaturated fatty acid/Polinezasićene } \\
\text { masne kiseline) }\end{array}$ & $4.61 \pm 0.45^{b}$ & $1.75 \pm 0.24^{\mathrm{a}}$ \\
\hline USFA/SFA (Saturated fat/Zasićena mast) & 0.83 & 0.55 \\
\hline
\end{tabular}

Legend/Legenda: ${ }^{\mathrm{a}, \mathrm{b}}$ Means within the same row with different superscripts differ significantly $(p<0.05)^{/ \mathrm{a}, \mathrm{b}}$ srednje vrednosti u istom redu sa različitim znakom se značajno razlikuju $(p<0,05)$

smoked ham originated from the same leg are presented in Table 4.

In this study, statistically significant differences $(p<0.05)$ were found for lightness $\left(\mathrm{L}^{*}\right)$ as well as for redness $\left(a^{*}\right)$ and yellowness $\left(b^{*}\right)$.

Meat has heterogeneous composition, which is specific for each type, and varies depending on many factors, therefore it is difficult to define the quality of the meat. Meat quality is affected by breed, gender, productivity and adaptation to stress, environment, management, nutrition, body weight and health condition at the time of slaughter, slaughter methods and post-slaughter carcass practices. In addition, meat products, in this case smoked ham, are manufactured in different ways and therefore it is difficult to compare the results represented by different authors. Previously, we examined chemical and sensory characteristics of meat from Bunte Deutsche Edelziege and Balkan goat breed (Ivanović et al., 2011) and meat quality of Serbian White goat and
Balkan goat (Ivanović et al., 2014). The results of chemical composition (total protein, fat, water, ash) and $\mathrm{pH}$ value of fresh meat presented in Table 1 are consistent with the results we obtained in the previous study, which related to the population of Serbian White goat (Ivanović et al., 2014). Our findings related to the fresh meat (Table 1) are also consistent with the results obtained by Paleari et al. (2008). These authors investigated the composition of meat from goat crosses (Frisa $\times$ Frontalasca) aged 2-3 years. Goats were reared in similar conditions as goats in our experiment (during summer season they were on pasture and during the winter kept inside facilities). Ding et al. (2010) investigated the quality of the meat from Guanzhong Dairy breed and three genotypes thereof. Our results relating to fresh meat, water, protein and ash are in agreement with the results of Ding et al. (2010) for the breed Guanzhong Dairy, however not in accordance regarding the fat. 
Table 3. Volatile compounds of fresh goat meat and smoked ham quantified by GC/MS $(\mu \mathrm{g} / \mathrm{kg})$

Tabela 3. Isparljiva jedinjenja u svežem kozijem mesu i u dimljenoj šunki kvantifikovana GC/MS ( $\mu \mathrm{g} / \mathrm{kg}$ )

\begin{tabular}{|c|c|c|}
\hline \multirow[b]{2}{*}{ Volatile compounds/Volatilna jedinjenja $\mathbf{n}=\mathbf{2 0}$} & \multicolumn{2}{|c|}{$\mathrm{M} \pm \mathrm{SD}$} \\
\hline & $\begin{array}{c}\text { Fresh meat } \\
\mathbf{n}=\mathbf{2 0}\end{array}$ & $\begin{array}{c}\text { Smoked ham } \\
n=20\end{array}$ \\
\hline \multicolumn{3}{|l|}{ Aldehydes/aldehidi } \\
\hline 3-methylbutanal/3-metilbutanal & $1.20 \pm 0.21^{\mathrm{a}}$ & $3.11 \pm 0.40^{\mathrm{b}}$ \\
\hline Pentanal/pentanal & $3.08 \pm 0.58^{\mathrm{b}}$ & $1.48 \pm 0.30^{\mathrm{a}}$ \\
\hline Hexanal/heksanal & $16.07 \pm 1.14^{b}$ & $5.96 \pm 1.05^{\mathrm{a}}$ \\
\hline Heptanal/heptanal & $2.31 \pm 0.28^{\mathrm{b}}$ & $1.06 \pm 0.18^{\mathrm{a}}$ \\
\hline Benzaldehyde/benzaldehid & $0.24 \pm 0.05^{\mathrm{a}}$ & $0.61 \pm 0.09^{\mathrm{b}}$ \\
\hline Octanal/oktanal & $1.77 \pm 0.24^{\mathrm{b}}$ & $0.37 \pm 0.07^{\mathrm{a}}$ \\
\hline Nonanal/nonanal & $2.98 \pm 0.35^{\mathrm{b}}$ & $0.52 \pm 0.12^{\mathrm{a}}$ \\
\hline \multicolumn{3}{|l|}{ Ketones/Ketoni } \\
\hline 2,3-butanedione/2,3-butanedion & $0.30 \pm 0.08^{\mathrm{a}}$ & $9.53 \pm 0.11^{b}$ \\
\hline 2-butanone/2-butanon & $3.65 \pm 0.33$ & n.d. \\
\hline 2-pentanone/2-pentanon & $0.14 \pm 0.03^{\mathrm{a}}$ & $0.72 \pm 0.35^{\mathrm{b}}$ \\
\hline 3-hydroxy-2-butanone/3-hidroksi-2-butanon & $0.17 \pm 0.04^{\mathrm{a}}$ & $22.25 \pm 1.75^{\mathrm{b}}$ \\
\hline 2-heptanone/2-heptanon & $0.30 \pm 0.05^{\mathrm{b}}$ & $0.24 \pm 0.05^{\mathrm{a}}$ \\
\hline 2,3-octanedione/2,3-oktanedion & $0.23 \pm 0.05^{\mathrm{a}}$ & $0.39 \pm 0.08^{b}$ \\
\hline \multicolumn{3}{|l|}{ Heterocyclic compounds/heterociklična jedinjenja } \\
\hline 2,6-dimethylpyrazine/2,6-dimetilpirazin & $0.11 \pm 0.03^{\mathrm{a}}$ & $0.25 \pm 0.05^{\mathrm{b}}$ \\
\hline \multicolumn{3}{|l|}{ Aromatic hydrocarbons/Aromatični vodougljenici } \\
\hline Benzene/benzen & n.d. & $0.46 \pm 0.10$ \\
\hline Methylbenzene/metilbenzen & $0.13 \pm 0.03^{\mathrm{a}}$ & $8.98 \pm 1.23^{b}$ \\
\hline Ethylbenzene/etilbenzen & n.d. & $0.43 \pm 0.09$ \\
\hline \multicolumn{3}{|l|}{ Phenols/Fenoli } \\
\hline Phenol/fenol & n.d. & $1.22 \pm 0.25$ \\
\hline 2-methyl-phenol/2-metil-fenol & n.d. & $0.40 \pm 0.08$ \\
\hline 2- methoxy-phenol/2-metoksi-fenol & n.d. & $1.28 \pm 0.25$ \\
\hline \multicolumn{3}{|l|}{ Alcohols/Alkoholi } \\
\hline 1-penten-3-ol & $0.22 \pm 0.04^{\mathrm{a}}$ & $1.64 \pm 0.31^{\mathrm{b}}$ \\
\hline 2-pentanol & $0.17 \pm 0.03$ & n.d. \\
\hline 3-methyl-1-butanol & $0.15 \pm 0.03^{\mathrm{a}}$ & $1.49 \pm 0.30^{\mathrm{b}}$ \\
\hline 1-pentanol & $1.16 \pm 0.20^{\mathrm{b}}$ & $0.61 \pm 0.12^{\mathrm{a}}$ \\
\hline Furfurol & $0.16 \pm 0.04^{\mathrm{a}}$ & $1.15 \pm 0.22^{\mathrm{b}}$ \\
\hline 1-octen-3-ol & $1.07 \pm 0.14$ & n.d. \\
\hline \multicolumn{3}{|l|}{ Organic acids/Organske kiseline } \\
\hline Acetic acid/Sirćetna kiselina & $0.29 \pm 0.05^{\mathrm{a}}$ & $3.63 \pm 0.55^{\mathrm{b}}$ \\
\hline Butanoic acid/Butanoinska kiselina & $0.65 \pm 0.10^{\mathrm{NS}}$ & $0.72 \pm 0.12^{\mathrm{NS}}$ \\
\hline 3-methyl-butanoic acid/3-metil-butanoinska kiselina & $0.10 \pm 0.03^{\mathrm{a}}$ & $1.66 \pm 0.27^{b}$ \\
\hline \multicolumn{3}{|l|}{ Alkanes/Alkani } \\
\hline Hexane/heksan & $0.27 \pm 0.05^{\mathrm{a}}$ & $5.87 \pm 0.95^{\mathrm{b}}$ \\
\hline Heptane/heptan & $0.15 \pm 0.03^{\mathrm{a}}$ & $0.82 \pm 0.38^{\mathrm{b}}$ \\
\hline Octane/oktan & $0.81 \pm 0.15^{\mathrm{NS}}$ & $0.84 \pm 0.15^{\mathrm{NS}}$ \\
\hline Nonane/nonan & $0.15 \pm 0.03^{\mathrm{a}}$ & $0.43 \pm 0.08^{b}$ \\
\hline \multicolumn{3}{|l|}{ Alkenes/Alkeni } \\
\hline 1-octene & $0.19 \pm 0.04^{\mathrm{a}}$ & $0.56 \pm 0.10^{\mathrm{b}}$ \\
\hline
\end{tabular}

Legend/Legend: a, b Means within the same row with different superscripts differ significantly $(p<0.05)$, NS - not statistically significant difference, nd - Not determined/a,b srednje vrednosti u istom redu sa različitim znakom se značajno razlikuju $(p<0,05)$, NS - nije statistički značajno; nd - nije određeno 
Table 4. Colour of fresh goat meat and smoked ham expressed in CIE L*a*b* system

Tabela 4. Boja svežeg kozijeg mesa i dimljene šunke izražena u CIE L*a*b* sistemu

\begin{tabular}{|l|c|c|}
\hline \multirow{2}{*}{ Parameter/Parametar, $\mathbf{n}=\mathbf{2 0}$} & \multicolumn{2}{|c|}{$\mathbf{M} \pm$ Sd } \\
\cline { 2 - 3 } & Fresh meat/Sveže meso & Smoked ham/Dimljena šunka \\
\hline Lightness/Svetla boja $-\mathrm{L}^{*}$ & $34.1 \pm 2.2^{\mathrm{b}}$ & $30.1 \pm 2.0^{\mathrm{a}}$ \\
\hline Redness/Crvena boja $-a^{*}$ & $20.9 \pm 1.8^{\mathrm{b}}$ & $17.1 \pm 1.5^{\mathrm{a}}$ \\
\hline Yellowness/Žuta boja $-b^{*}$ & $5.2 \pm 1.1^{\mathrm{b}}$ & $3.3 \pm 0.9^{\mathrm{a}}$ \\
\hline
\end{tabular}

Legend/Legenda:a, b Means within the same row with different superscripts differ significantly $(p<0.05)^{/ \mathrm{a}, \mathrm{b}}$ srednje vrednosti $\mathrm{u}$ istom redu sa različitim znakom se značajno razlikuju $(p<0,05)$

In our studies, the most represented fatty acids in fresh meat were, in the following order, oleic acid, palmitic acid, stearic acid, myristic acid and palmitoleic acid. The percentages of these fatty acids in smoked ham are little different (Table 2). Statistically significant differences in regard tio the fatty acid composition in fresh meat and smoked ham are the result of manufacturing process (maturation, curing, smoking, drying). Fatty acid composition in meat and milk of ruminants depends on breed and feeding (Grubić et al., 2005; Ivanović et $a l ., 2012$ ). Lipids from the diet are hydrolyzed in the rumen of ruminants. Unsaturated fatty acids from food are biohydrogenated by microorganisms from rumen. As a result, ruminants absorb predominantly saturated fatty acids, which is why the food that originates from ruminants contains mainly saturated fatty acids. Our results showed that the total saturated fatty acids participate with $54.53 \% \pm 5.27$ in fresh meat and $64.47 \pm 6.37$ in smoked ham. The USFA/SFA ratio in fresh meat was 0.83 and in smoked ham 0,55 . The results obtained in the present study for oleic acid, palmitic acid and stearic acid in fresh meat are in accordance with the results obtained by Paleari et al. (2008), while for the smoked ham are consistent only for oleic acid, which is understandable, because the production process is not the same. Our results regarding the total SFA, MUFA and PUFA contents are also consistent with the results of previously mentioned authors. The results obtained for fresh meat, that are related to percentage of oleic acid, palmitic acid, stearic acid and myristic acid are in agreement with the results obtained by Mushi et al. (2008), but not in agreement with the results from same study relating to the total SFA, MUFA and PUFA content.

it The presence of volatile compounds was determined in the analysed samples within the following groups: aldehydes, ketones, heterocyclic compounds, aromatic hydrocarbons, phenols, alcohols, organic acids, alkanes (Table 3). By analysing the samples of fresh meat, two compounds from the group of aromatic hydrocarbons (benzene and ethylbenzene) and compounds from the group of phenols (phenol, 2-methyl- phenol and 2- methoxyphenol), which were identified in smoked ham, were not determined. By analysing the samples of smoked ham, the presence of mentioned compounds was determined, however, in the group of ketones, 2-butanone was not determined, and in the group of alcohols, 2-pentanol and 1-octen-3-ol compounds were not identified. The compounds identified in smoked ham probably were formed as a result of smoking.

Aldehydes were the most common groups of compounds identified in the analysed samples. Hexanal, $16.07 \pm 1.14 \mu \mathrm{g} / \mathrm{kg}$ in fresh meat and $5.96 \pm 1.05 \mu \mathrm{g} / \mathrm{kg}$ in smoked ham, was the most common type of aldehyde. Hexanal mainly comes from linoleic and arachidonic acid (Martin et al., 2002). Our results regarding the aldehyde in smoked ham are in agreement with results from study conducted by Paleari et al. (2008). Values of aldehyde in the fresh meat do not agree with results obtained by Kang et al. (2013), but are in agreement with ones obtained by Villalobos-Delgado et al. (2014). These authors have examined the fresh sheep meat during production process. Aldehydes in general are major sources of volatile fractions obtained from ruminant meat (Vasta and Priolo, 2006). According to Mottram (1998), aldehydes are compounds which are formed as a result of lipids oxidation. They may significantly contribute to the overall taste of the product because of their low levels of olfactory perception.

The second most present group of compounds are ketones. 2-butanone is mainly determined in fresh meat, while its presence was not determined in the smoked ham. Most common ketones found in smoked ham were 3-hydroxy-2-butanone and 2,3-butanedione. Type and amounts of ketones, as well as aldehydes, in smoked ham in our study are in agreement with the resultes obtained by Paleari 
et al. (2008), while the ones found in fresh meat are contrary to the results obtained by Kang et al. (2013), but agree with results from study conducted by Villalobos-Delgado et al. (2014). Detection of the ketones in the meat is generally correlated with type of diet. It has been found that 2,3-octanedione is present in a higher amount in meat from the animals fed with grass (Vasta and Priolo, 2006).

The results in our study referring to aromatic hydrocarbons obtained for smoked ham are in agreement with the results from study conducted by Paleari et al. (2008). In fresh meat two of three compounds were not detected (Table 3 ).

Phenols were not detected in fresh meat while they were present in small amounts in smoked ham. Also organic acids were present in a small percentage in fresh meat (Table 3), although they are responsible for the distinct taste of goat meat. Their level in final product was slightly higher, especially amount of acetic acid. Our results for acetic acid in smoked ham are in agreement with the results from study conducted by Paleari et al. (2008). Other compounds such as alcohols, alkanes and alkenes were detected in very low concentrations, but they probably have synergistic effects with other compounds and can affect the smell and the taste of goat meat and meat products.

\section{References}

Anaeto M., Adeyeye A. J., Chioma O. G., Olarinmoye O. A., Tayo O. G., 2010. Goat products: Meeting the challenges of human health and nutrition. Agriculture and Biology Journal of North America, 2010, http://www.scihub. org/ABJNA

Biswas S., Das K. A., Banerjee R., Sharma N. 2007. Effect of electrical stimulation on quality of tender stretched chevon sides. Meat Science, 75, 332-336.

Casey N. H., Webb C. E., 2010. Managing goat production for meat quality. Small Ruminant Research, 89, 218-224.

CIE Colorimetry, 1986. (2nd ed.), Publication CIE No. 15.2, Vienna: Central Bureau of the Commission Internationale de L'Ectarge.

Ding W., Kou L., Cao B., Wei Y., 2010. Meat quality parameters of descendants by grading hybridization of Boer goat and Guanzhong Dairy goat. Meat Science, 84, 323-328.

Grubić G., Đorđević N., Glamočić D., Stojanović B., Adamović O., 2005. Uticaj ishrane krava na sintezu nekih sastojaka mlečne masti. Simpozijum Mleko i proizvodi od mleka. Biotehnologija u stočarstvu, 21, 29-41.

Ivanović S., Žutić M., Pavlović I., Žujović M., 2009. Goat meat - important food stuff or vector of zoonotic microorganisms. Proceedings, IV International symposium of livestock production, Struga, Makedonija, 65 .
Statistically significant differences between the parameters which determine the colour of fresh meat and smoked ham were expected because the processes during the production of smoked ham (maturation, curing and smoking) leads to discoloration. The results obtained in this study (Table 4) relating to fresh meat are in agreement with our previous research (Ivanović et al., 2014) but not with the results of Madruga et al. (2008). The results of measurements of colour in fresh meat obtained in the study conducted by Teixeira et al. (2011), referring to the parameter $\mathrm{L}^{*}$ are in agreement with our results, while the parameters $\mathrm{a}^{*}$ and $\mathrm{b}^{*}$ are not compatible.

\section{Conclusion}

The statistical difference between individual fatty acides in fresh and smoked meat lead to complex chemical and biochemical processes during technological production (maturation, brine, smoking, drying). As result of these processes, some volatile compounds, which were present in fresh meat, were probably synthesized in the whole group of other compounds that are present only in smoked meat. All the changes that have occurred, have led to significant differences $(p<0.05)$ in colour between samples of fresh and smoked meat.

Ivanović S., Popov-Raljic J., Baltic Z. M., Zujovic M., M. Tomic M., Lilic S., Pavlović I., 2011. Chemical and sensory characteristics of Bunte Deutsche Edelziege and Balkan goat meat. African Journal Biotechnology, 80, 1843318439.

Ivanović S., Teodorović V., Baltić Ž. M., 2012. Kvalitet mesa: biološke i hemijske opasnosti. Izd. Naučni institut za veterinarstvo Srbije, 2012, 356.

Ivanović S., Stojanović Z., Nesić K., Pisinov B., Baltić Ž. M., Popov-Raljić J., Đurić J., 2014. Effect of goat breed on the meat quality. Hemijska industrija, OnLine-First (00):6-6 DOI:10.2298/HEMIND1312010061.

Kang G., Soohyun C., Pilnam S., Beomyoung P., Sangwoo K., Donghun K., Youngjun K., Sunmun K., Kyoungmi P.. 2013. Effects of high pressure processing on fatty acid composition and volatile compounds in Korean native black goat meat. Meat Science, 94, 495-499.

Likens S. T., Nickerson G. B., 1964. Detection of certain hop oil constituents in brewing products. American Society of Brewing Chemists, 5-13.

Machiels D., Istasse L., Van Ruth M. S., 2004. Gas chromatography-olfactometry analysis of beef meat originating from differently fed Belgian Blue, Limousin and Aberdeen Angus bulls. Food Chemistry, 86, 377-383. 
Madruga M. S., Torres S. T., Carvalho F. F., Queiroga C. R., Narain N., Garrutti D., Souza A. M., Carla N., Mattos W., Costa G. R., 2008. Meat quality of Moxoto and Caninde goats as affected by two levels of feeding. Meat Science, 80, 1019-1023.

Martin L., Timon L. M., Petron J. M., Ventanas J., Antequera T., 2002. Evolution of volatile aldehydes in Iberian ham matured under different processing condition. Meat Science, 54, 323-327.

Mottram D. S., 1998. Flavour formation in meat and meat products: a review. Food Chemistry, 62, 415-424.

Mushi D. E., Eik O. L., Thomassen S. M., Sørheim O., Ådnøy T., 2008. Suitability of Norwegian short-tail lambs, Norwegian dairy goats and Cashmere goats for meat production - Carcass, meat, chemical and sensory characteristics. Meat Science, 80, 842-850.

Paleari M. A., Moretti M. V., Beretta G., Caprino F., 2008. Chemical parameters, fatty acids and volatile compounds of salted and ripened goat thigh. Small Ruminant Research, 74, 140-148.
Teixeira A., Pereira E., Rodrigues S. E., 2011. Goat meat quality, Effects of salting, air-drying and ageing processes. Small Ruminant Research 98, 55-58.

Todaro M., Corrao A., Alicata L. M., Shinelli R., Giaccone P., Priolo A., 2004. Effects of litter size and sex on meat quality traits of kid meat, Small Ruminant Research, 54, 191-196.

Vasta V., Priolo A., 2006. Ruminant fat volatiles as affected by diet. Meat Science, 73, 218-228.

Villalobos-Delgado H. L., Caro I., Blanco C., Morán L., Prieto N., Bodas R., Giráldez F. J., Mateo J., 2014. Quality characteristics of a dry-cured lamb leg as affected by tumbling after dry-salting and processing time. Meat Science, 97, 115-122.

Webb E. C., Casey H. N, Simela L., 2005. Goat meat quality. Small Ruminant Research, 60, 153-166.

Wood J. D., Richardson I. R., Nute R. G., Fisher V. A., Campo M. M., Kasapidou E., Sheard R. P., Enser M., 2004. Effects of fatty acids on meat quality: A review. Meat Science, 66, 21-32.

\title{
Promene kvaliteta mesa koza u procesu dobijanja dimljene šunke
}

\author{
Ivanović Snežana, Pisinov Boris, Bošković Marija, Ivanović Jelena, Marković Radmila, Baltić Ž. Milan, \\ Nešić Ksenija
}

R e z i m e: Kvalitet svežeg mesa koza može se definisati strogo u smislu fizičkih i hemijskih osobina, ili u smislu percepcije potrošača. U Srbiji se malo zna o kvalitetu kozjeg mesa i proizvoda od kozjeg mesa, kao što je dimljena šunka. Cilj ovog istraživanja bio je da se utvrde razlike u osnovnom hemijskom sastavu, boji, sastavu masnih kiselina, volatilnih materija u svežem mesu i dimljenoj šunki (m. superficial gluteal). Meso je dobijeno klanjem koza iz populacije srpske bele koze, starih pet-šest godina. Za određivanje navedenih parametara kvaliteta korišćene su ISO metode.

Između utvrđenih vrednosti proteina, masti, vode, pepela, $p H$ vrednosti, masnih kiselina i isparljivih materija utvrđenih u svežem mesu i gotovom proizvodu (dimljena šunka) postojala je statistički značajna razlika $(p<0,05)$. U svežem mesa nisu utvrđena dva jedinjenja iz grupe aromatičnih ugljovodonika i jedinjenja iz grupe fenola. Pretpostavlja se da su složeni hemijski i biohemijski procesi tokom proizvodnje (zrenje, salamurenje, dimljenje, sušenje) doveli do statistički značajne razlike između ispitivanih parametara kvaliteta u svežem i dimljenom mesu. Utvrđena je statistički značajna razlika $(p<0,05)$ između vrednosti kaprinske kiseline, laurinske kiseline, miristinske kiseline, pentadekanske kiseline, palmitinske kiseline, palmitoleinske kiseline, heptadekanske kiseline, stearinske kiseline, oleinske kiseline, linolne kiseline, linolenske kiseline, arahidonske kiseline i gadoleinske kiseline u svežem mesu pripremljenom za sečenje i dimljenje u odnosu na vrednosti ovih masnih kiselina identifikovanih u gotovom proizvodu (šunka).

Ključne reči: koze, meso, kvalitet, zrenje, salamurenje, dimljenje.

Paper received: 1.10 .2014 .

Paper corrected: $28 \cdot 10.2014$.

Paper accepted: 31.10 .2014 . 